\title{
ANALYSIS OF CREATIVE THINKING ABILITY IN THE IMPLEMENTATION OF THEMATIC LEARNING IN CLASS V STUDENTS OF SD N 1 PANJER ACADEMIC YEAR 2018/2019
}

\author{
Peni Setyorini, Nurhasanah, Kartika Chrysti Suryandari \\ Universitas Sebelas Maret \\ peni.setyorini21@gmail.com
}

Article History

accepted 30/09/2018

approved 12/10/2018

published 30/10/2018

\section{Keywords}

creative thinking, learning, thematic

\begin{abstract}
Thematic learning is divided into themes that combine several subjects of learning. The ability to think creatively should be formed from an early age to meet the golden generation of 2045. The purpose of this study was to analyze the ability to think creatively in the application of thematic learning in class $V$ students of SD Negeri 1 Panjer in 2018/2019 academic year. This study used descriptive qualitative method. The research subjects were the fifth grade students of SD Negeri 1 Panjer namely 19 male students and 8 female students. Data obtained from questionnaires, interviews, and observations. The results of the analysis of the creative thinking abilities of fifth grade students of SD Negeri 1 Panjer are categorized quite good, but it needs improvement in several aspects to achieve the golden generation in 2045. Aspects that need to be improved include aspects of flexible thinking, original thinking, and detailing.
\end{abstract}

Social, Humanities, and Education Studies (SHEs): Conference Series https://jurnal.uns.ac.id/shes
p-ISSN 2620-9284 e-ISSN 2620-9292 


\section{PENDAHULUAN}

Kurikulum 2013 merupakan yang bertujuan mempersiapkan manusia Indonesia agar memiliki kemampuan hidup sebagai pribadi dan warga negara yang beriman, produktif, kreatif, inovatif, dan afektif serta mampu berkontribusi pada kehidupan bermasyarakat, berbangsa, bernegara dan peradaban dunia. Untuk menciptakan manusia yang kreatif dapat dicapai dengan pendidikan. Berdasarkan Undang-Undang No 20 tahun 2003 "pendidikan adalah usaha sadar dan terencana untuk mewujudkan suasana belajar dan proses pembelajaran agar peserta didik secara aktif mengembangkan potensi dirinya untuk memiliki kekuatan spiritual keagamaaan, pengendalian diri, kepribadian, kecerdasan, akhlak mulia, serta keterampilan yang diperlukan dirinya, masyarakat, bangsa, dan Negara.". Potensi yang dimiliki oleh setiap siswa harus dikembangkan untuk mencapai tujuan dari pendidikan sehingga siswa dapat mencapai kehidupan yang lebih bermakna.

Pendidikan pada masa sekarang ini harus bisa menghasilkan sumber daya manusia yang dapat menyongsong generasi emas 2045. Dongoran (2014) meyatakan bahwa "pendidikan merupakan sebuah investasi yang memiliki peranan strategis dalam mengembangkan sumber daya manusia yang berkualitas dengan merekonstruksi dan mereformasi desain pendidikan sehingga mendukung tercapainya generasi emas pada 2045".

Generasi emas tahun 2045 dapat dimulai dengan mengembangkan keampuan berpikir kreatif sesuai dengan tujuan kurikulum 2013. Menurut Ahmadi (2013:31) berpikir kreatif adalah "menciptakan ide dan karya baru yang berbeda dari yang biasa dan pemikiran yang mampu mengemukakan ide atau gagasan yang memiliki nilai tambah". Menurut Iskandar (2009:88) berpikir kreatif merupakan "menggunakan pemikiran dalam mendapatkan ide baru, menciptakan yang baru berdasarkan kepada keaslian dalam penghasilannya dan dapat diberikan dalam bentuk ide yang nyata ataupun abstrak". Menurut Sugiarti,T,Sunardi,dan Desbi (2016) menyatakan bahwa "untuk bisa berpikir kreatif seseorang tidak dipengaruhi oleh IQ melainkan kreativitas tersebut timbul karena pengalaman atau proses-proses yang terjadi di sekitar lingkungan".

Torrance (1972) dalam (Suryandari,K,Sajidan,Rahardjo,dan Prasetyo,2017:134) dimensi berpikir kreatif meliputi: a) fluenty (kemampuan untuk berpikir untuk mendapatkan ketepatan dan kelancaran ide), b) originality (kemampuan berpikir orisinil dan unik, c) elaboration (kemampuan mengembangkan dan mengelaborasi ide secara terperinci), d) flexibility (kemampuan untuk memahami fokus permasalahan secara luwes).

Berdasarkan beberapa pendapat ahli di atas, dapat diketahui bahwa berpikir kreatif adalah pemikiran dalam mendapatkan atau menciptakan karya baru dalam bentuk nyata atau abstrak berupa dimensi keterampilan berpikir lancar, kemampuan berpikir luwes, keterampilan berpikir orisinil dan keterapiilan memerinci guna menghasilkan nilai tambah yang dapat timbul karena pengalaman yang terjadi di lingkunga. Namun pada kenyataanya tingkat berpikir kreatif siswa masih rendah terbukti dari adanya berita berita "Mengenal 'HOTS' Penyebab Soal UNBK Dikeluhkan Begitu Sulit" yang ditulis oleh detiknews (2018).

Berdasarkan fakta yang tersebut dapat diketahui bahwa tingkat berpikir kreatif siswa masih rendah, terbukti dari banyaknya siswa yang mengeluhkan soal UN yang susah karena menggunakan HOTS sehingga menuntut siswa untuk berpikir kreatif untuk dapat menyelesaikan soal. Untuk bisa mendapatkan manusia yang berpikir kreatif di kemudian hari, maka perlu adanya penanaman sikap berpikir kreatif yang dimiliki oleh setiap sisa guna menghadapi generasi emas 2045 sejak dini. Sejalan dengan hal tersebut Suriyani,Hastratuddin,dan Asmin (2015:227) yang menyatakan bahwa "pengembangan berpikir kreatif memang perlu dilakukan karena kemampuan ini merupakan salah satu kemampuan yang dikehendaki dunia kerja". Akan tetapi, pada 
kenyaataanya masih banyak siswa yang belum dapat berpikir kreatif untuk menyelesaikan permasalahan yang ada.

Peneliti tertarik melakukan penelitian di sekolah dasar karena tercapainya generasi emas 2045 dapat dilihat dari tingkat berpikir kreatif siswa khususnya siswa SD karena pada tahun 2045 siswa SD memasuki usia produktif. Tercapainya generasi emas 2045 tergantung pada kemampuan berpikir kreatif siswa SD pada saat ini. Tujuan penelitian ini adalah untuk menganalisis kemampuan berpikir kreatif dalam penerapan pembelajaran tematik kepada siswa di kelas V SD Negeri 1 Panjer tahun ajaran 2018/2019.

Berdasarkan infomasi yang diperoleh, maka peneliti memutuskan untuk melakukan penelitian dengan judul "Analisis Kemampuan Berpikir Kreatif dalam Penerapan Pembelajaran Tematik pada Siswa Kelas V SD N 1 Panjer Tahun Ajaran 2018/2019.

\section{METODE}

Pada penelitian ini menggunakan penelitian deskriptif sederhana. Penggunaan penelitian deskriptif pada penelitian ini karena peneliti tidak melakukan tindakan terhadap subjek yang diteliti. Peneliti hanya melakukan observasi, wawancara, dan angket untuk mendapatkan data.

Penelitian ini dilaksanakan pada 12-15 September 2018 Di SD Negeri 1 Panjer beralamat di jalanTelasih No. 80 Panjer, Kecamatan Kebumen, Kabupaten Kebumen, Jawa Tengah. Subjek penelitian ini adalah siswa kelas V SD Negeri 1 Panjer tahun ajaran 2018/2019, yang terdiri dari 27 siswa yang terdiri dari 19 laki-laki dan 8 perempuan. Data dalam penelitian ini berupa data kualitatif kemampuan berpikir kreatif siswa yang terlihat dari kriteria sangat baik, baik, cukup, dan kurang baik. Pengambilan data pada penelitian ini menggunakan observasi dan wawancara.

Teknik analisis data pada penelitian ini adalah dengan mengunakan analisis deskriptif, data dan informasi yang didapatkan dideskripsikan secara kualitatif. Data yang dieproleh dijelaskan secara deskriptif. Berpikir kreatif siswa diamati melalui observasi yang dilakukan oleh peneliti pada saat pembelajaran tematik. Selain itu, peneliti melakukan wawancara dengan siswa menggunakan pedoman wawancara.

Analisis yang dilakukan dalam penelitian ini dengan menghitung skor pada setiap aspek yang diamati yaitu 0-0,25\% termasuk kategori kurang baik;26-50\% kategori cukup; 51-75\% kategori baik; 76-100\% kategori sangat baik.

\section{HASIL DAN PEMBAHASAN}

Penelitian ini digunakan untuk menganalisis berpikir kreatif siswa dalam pembelajaran tematik yang terlihat dari 4 aspek berpikir kreatif menurut Torrance (1972) dalam (Suryandari,K,Sajidan,Rahardjo,dan Prasetyo dkk,2017:134) yang meliputi 4 indikator yaitu : a) fluenty (kemampuan untuk berpikir untuk mendapatkan ketepatan dan kelancaran ide), b) originality (kemampuan berpikir orisinil dan unik, c) elaboration (kemampuan mengembangkan dan mengelaborasi ide secara terperinci), d) flexibility (kemampuan untuk memahami fokus permasalahan secara luwes). Hasil observasi peneliti, berpikir kreatif yang terdiri dari empat indikator sebagai berikut. 
Tabel 1. Berpikir Kreatif

\begin{tabular}{|c|c|c|c|c|c|}
\hline \multirow[t]{2}{*}{ Aspek } & \multirow[t]{2}{*}{ Indikator } & \multicolumn{4}{|c|}{ Persentase (\%) } \\
\hline & & 1 & 2 & 3 & 4 \\
\hline \multirow{3}{*}{$\begin{array}{l}\text { 1. Fluency } \\
\text { (keterampilan } \\
\text { berpikir lancar) }\end{array}$} & $\begin{array}{l}\text { 1. Mampu mengajukan } \\
\text { lebih dari } 2 \text { pertanyaan. }\end{array}$ & 8 & 0 & 48 & 44 \\
\hline & $\begin{array}{l}\text { 2. Mampu mengemukakan } \\
\text { pendapat sesuai dengan } \\
\text { permasalahan. }\end{array}$ & 0 & 8 & 52 & 40 \\
\hline & $\begin{array}{l}\text { 3. Siswa mampu menjawab } \\
\text { pertanyaan lebih dari } \\
\text { satu jawaban. }\end{array}$ & 0 & 52 & 8 & 40 \\
\hline \multirow{3}{*}{$\begin{array}{l}\text { 2. Flexibility } \\
\text { (keterampilan } \\
\text { berpikir luwes) }\end{array}$} & $\begin{array}{l}\text { 1. Menghasilkan berbagai } \\
\text { macam ide. }\end{array}$ & 40 & 60 & 0 & 0 \\
\hline & $\begin{array}{l}\text { 2. Menyelesaikan masalah } \\
\text { dari berbagai sudut } \\
\text { pandang. }\end{array}$ & 40 & 52 & 8 & 0 \\
\hline & $\begin{array}{l}\text { 3. Menyelesaikan masalah } \\
\text { dari dengan berbagai } \\
\text { macam cara. }\end{array}$ & 28 & 44 & 24 & 4 \\
\hline \multirow[t]{3}{*}{$\begin{array}{l}\text { 3. Originality } \\
\text { (keterampilan } \\
\text { berpikir orisinil) }\end{array}$} & $\begin{array}{l}\text { 1. Menemukan pemikiran } \\
\text { unik untuk } \\
\text { meneyelesaikan } \\
\text { masalah. }\end{array}$ & 40 & 28 & 20 & 12 \\
\hline & $\begin{array}{l}\text { 2. Memikirkan cara baru } \\
\text { untuk menyelesaikan } \\
\text { masalah. }\end{array}$ & 44 & 36 & 20 & 0 \\
\hline & $\begin{array}{l}\text { 3. Menggabungkan cara } \\
\text { menyelsaikan masalah } \\
\text { dengan pola yang sudah } \\
\text { ada dengan yang baru. }\end{array}$ & 48 & 44 & 8 & 0 \\
\hline \multirow{3}{*}{$\begin{array}{l}\text { 4. Elaboration } \\
\text { (keterampilan } \\
\text { memerinci) }\end{array}$} & $\begin{array}{l}\text { 1. Memerinci gagasan } \\
\text { secara detail. }\end{array}$ & 12 & 44 & 32 & 12 \\
\hline & $\begin{array}{l}\text { 2. Memerinci pertanyaan } \\
\text { secara detail. }\end{array}$ & 28 & 60 & 8 & 4 \\
\hline & $\begin{array}{l}\text { 3. Menjawab pertanyan } \\
\text { terperinci }\end{array}$ & 32 & 40 & 12 & 16 \\
\hline
\end{tabular}

Berdasarkan hasil angket dan wawancara yang terdapat pada tabel berpikir kreatif siswa kelas $\mathrm{V}$, maka data yang diperoleh:

1. Fluency (keterampilan berpikir lancar)

a. Mampu mengajukan lebih dari 2 pertanyaan.

Berdasarkan hasil angket dan wawancara, siswa mengajukan lebih dari 2 pertanyaan ketika siswa ingin lebih mengetahui sesuatu yang belum diketahui secara lebih dalam.

b. Mampu mengemukakan pendapat sesuai dengan permasalahan.

Siswa mampu mengemukakan pendapat sesuai dengan permasalahan ketika siswa diberi permasalahan oleh guru saat pembelajaran berlangsung.

c. Siswa mampu menjawab pertanyaan lebih dari satu jawaban. 
Berdasarkan hasil angket dan wawancara siswa mampu menjawab pertanyaan lebih dari satu jawaban ketika guru memberikan pertanyaan yang menuntut siswa untuk berpikir lanjut.

2. Flexibility (keterampilan berpikir luwes)

a. Menghasilkan berbagai macam ide.

Berdasarkan hasil angket dan wawancara, siswa dapat menghasilkan berbagai macam ide ketika siswa diberikan pancingan oleh guru.

b. Menyelesaikan masalah dari berbagai sudut pandang.

Siswa sebenarnya sudah bisa menyelesaikan masalah dari berbagai sudut pandang, namun dalam penyelesaiannya harus selalu diberikan rangsangan oleh guru.

c. Menyelesaikan masalah dari dengan berbagai macam cara.

Berdasarkan angket dan wawancara siswa dapat menyelesaikan masalah dari dengan berbagai macam cara, akan tetapi pada awal menjawab siswa masih ragu dalam menjawab karena pendaapat yang diutarakan dalam menyelesaikan masalah berbeda dengan buku.

3. Originality (keterampilan berpikir orisinil)

a. Menemukan pemikiran unik untuk menyelesaikan masalah.

Siswa belum bisa menemukan pemikiran yang unik untuk menyelesaikan masalah.

b. Memikirkan cara baru untuk menyelesaikan masalah.

Berdasarkan hasil angket dan wawancara, siswa dalam menyelesaikan masalah masih terpaku pada buku.

c. Menggabungkan cara menyelesaikan masalah dengan pola yang sudah ada dengan yang baru.

Siswa belum terlihat dapat menyelesaikan masalah dengan menggabungkan antara pola yang ada dengan pola yang baru.

4. Elaboration (keterampilan memerinci)

a. Memerinci gagasan secara detail.

Siswa dalam mengemukakan gagasan sudah mulai bisa secara detail tetapi masih ragu dalam menyampaikan.

b. Memerinci pertanyaan secara detail

Dalam memerinci pertanyaan secara detail berdasarkan observasi yang dilakukan siswa sudah dapat tetapi tingkat kedetailannya masih rendah.

c. Menjawab pertanyaan terperinci.

Siswa dalam menjawab pertanyaan secara terperinci berdasarkan hasil observasi yang dilakukan oleh peneliti siswa memberikan jawaban terperinci jika guru dalam memberikan pertanyaan secara terperinci juga.

Aspek yang ditekankan pada penelitian ini adalah keterampilan berpikir lancar, keterampilan berpikir luwes, kemampuan berpikir orisinil, dan keterampilan memerinci. Berikut ini merupakan uraiannya:

1. Keterampilann berpikir lancar

Berdasarkan data hasil angket dan wawancara, kemampuan siswa dalam mengajukan lebih dari 2 pertanyaan misalnya ketika saat pembelajaran materi kegiatan ekonomi siswa bertanya lebih dalam pelaku-pelaku ekonomi dalam kegiatan ekonomi. Siswa juga mampu mengemukakan pendapat sesuai dengan permasalahan ketka diberi permasalahan oleh guru saat pembelajaran. dalam menjawab pertanyaan yang diberikan oleh guru siswa mampu menjawab lebih dari satu jawaban.

2. Keterampilan berpikir luwes

Berdasarkan data hasil angket dan wawancara siswa dalam menghasilkan berbagai macam ide ketika siswa diberi pertanyaan pancingan oleh guru dengan mengaitkan dengan kehidupan sehari-hari mereka. Seperti halnya menghasilkan berbagai macam ide, dalam menyelesaikan masalah dari berbagai sudut pandang siswa juga harus diberi rangsangan terlebih dahulu oleh guru. Penyelesaian masalah dengan berbagai macam cara mulai terlihat akan tetapi ketika siswa ditanya pemecahan masalah siswa masih ragu dalam menjawab karena menurut siswa jawaban yang berbeda dengan buku belum sepenuhnya benar. 
3. Keterampilan berpikir orisinil

Berdasarkan data hasil angket dan wawancara, siswa dalam menemukan pemikiran unik, memikirkan cara baru, dan menggabungkan cara penyelesaian masalah dengan pola yang sudah ada dengan yang baru belum terlihat, hal ini dapat dilihat saat siswa menyelesaikan masalah yang diajukan oleh guru.

4. Keterampilan memerinci

Berdasarkan data hasil angket dan sudah mulai bisa tetapi masih ragu dalam menjawab ditunjukan ketika siswa diberi diberi pertanyaan oleh guru tentang kegiatan ekonomi dalam mengemukakan pendapat siswa bisa mengemukakan gagasan mulai dari jenis kegiatan ekonomi dan contoh kegiatannya dalam kehidupan sehari-hari. Siswa akan memerinci pertanyaan secara detail sudah dapat tetapi masih rendah terlihat saat guru menyajikan media gambar siswa hanya bertanya hal-hal yang bersifat umum. Siswa menjawab pertanyaan terperinci ketika guru memberikan pertanyaan secara terperinci juga misalnya, saat ditanya tentang proses produksi suatu barang siswa hanya menjawab secara ingatan mereka bukan menjawab berdasarkan kenyataan di lapangan.

\section{SIMPULAN}

Berdasarkan data yang diperoleh peneliti, maka dapat disimpulkan bahwa kemampuan berpikir kreatif siswa kelas V SD Negeri 1 Panjer masuk dalam kategori cukup baik. Akan tetapi diperlukan adanya peningkatan pada beberapa aspek untuk mencapai generasi emas pada 2045. Aspek yang perlu ditingkatkan diantaranya pada aspek keterampilan berpikir luwes, keterampilan berpikir orisinil, dan keterampilan memerinci.

\section{DAFTAR PUSTAKA}

Ahmadi, A. (2013). Psikologi Belajar. Jakarta:Rineka Cipta.

Detiknews.(2018, April 17). Mengenal 'HOTS' Penyebab Soal UNBK Dikeluhkan Begitu Sulit. Detiknews. Diakses dari https://news.detik.com/

Dongoran, Faisal R. (2014). Paradigma Membangun Generasi Emas 2045 dalam Perspektif Filsafat Pendidikan.Jurnal Tabularasa PPS UNIMED Vol. II No.1.

Iskandar. (2009). Psikoloi Pendidikan. Ciputat:GP Press.

Sugiarti,T., Sunardi, dan Desbi. (2016).Analisis Kemampuan Berpikir Kreatif Siswa Dalam Memecahkan Masalah Divergen Sub Pokok Bahasan Segitiga Dan Segiempat Berdasarkan Kemampuan Matematika.Kadikma, Vol 7, No.1.

Suryandari,K, Sajidan, Rahardjo, dan Prasetyo. (2017). Analisis Pembelajaran Konstruktivisme Melalui Strategi Preview Question Read Reflect Recite Review (PQ4R) Terhadap Kemampuan Berpikir Kreatif Mahasiswa PGSD. Inovasi Pendidikan, 2017, 133.

Suriyani,Hastratuddin,dan Asmin. (2015). Peningkatan Kemampuan Berpikir Kreatif dan Kemandirian Belajar Siswa MTs Negeri 2 Medan Melalui Pembelajran Matematika dengan Pendekatan Open-Ended.Jurnal Tabularasa PPS UNIMED Vol. 12 No.3

Sekretaris Negara Republik Indoenesia. (2003). Undang-undang Nomor 20 Tahun 2003 tentang Sistem Pendidikan Nasional. Jakarta: Penulis. 